\title{
ARCHITECTURAL COST PREDICTIONS: A LEGAL AND INSTITUTIONAL ANALYSIS
}

\author{
Justin Sweet* and Lesly Sweet**
}

\begin{abstract}
A CRISIS IN THE ARCHITECT-CLIENT RELATIONSHIP often results when the construction bids substantially exceed anticipated costs. If the client decides to give up the project, he and the architect may disagree upon the architect's right to be paid for prior architectural services. The disagreement may raise a number of legal issues, including the parol evidence rule, implication of terms, interpretation, and the doctrine of conditions.
\end{abstract}

That such problems frequently arise was confirmed by a recent survey of practicing architects. In this survey six hundred questionnaires were sent to practicing architects in Northern California. Of the 281 who responded, 55 percent had had difficulties with their clients in the three years preceding this survey when the low bid substantially exceeded anticipated costs.

This Article will look at the background of such cost problems, analyze the legal issues, and suggest methods to the legal profession for preventing or resolving such problems.

\footnotetext{
*B.A., 1951, University of Wisconsin; LL.B., 1953, University of Wisconsin; Professor of Law and Visiting Professor of Architecture, University of California, Berkeley.

**B.A., 1953, University of Wisconsin; J.D., 1965, Hastings College of Law. Member of the California Bar. 1967).

Portions of this article originally appeared in Creative Control of Building Costs (W. Hunt ed.

'Unpublished survey on file with the California Law Review.

Question 15 reads:

"In the past 3 years (or since you have been admitted to practice, whichever is less) have you had difficulty or a misunderstanding with a client over excess costs?"

Yes 148

No 126

Questionnaires were sent to members of the Northern California and East Bay American Institute of Architects (AIA) chapters. Respondents did not have to give their names. Of the 281 who responded, 59 had been licensed for one to five years, 76 from six to ten years, and 141 over ten years. Seventy-six indicated an income from $\$ 5,000-10,000,130$ from $\$ 10,000-20,000$ and 64 over $\$ 20,000$. As for office size, 73 practiced by themselves, 143 in offices of one to four architects, 76 in offices from five to ten and 19 in offices with over ten architects. The work done by the responders was varied, including private residences, commercial, and public work.
} 


\section{THE SETTING}

It may be useful to describe briefly the way in which cost problems develop. There are a number of variations but a routine pattern does emerge. Assume an individual wishes to construct a project. The client will inform the architect of his needs and his desires. He will roughly describe the type of structure he wants in terms of quantity and, usually more vaguely, in terms of quality. He will, as a rule, indicate about how much he wishes to spend. The client consults an architect to obtain professional design advice and to ascertain if and how his objectives can be achieved. Obviously, the factors may not prove compatible. The client may not be able to get the quantity and quality at the price he would like to spend. In order to achieve the solution it may be necessary to cut back on quantity and quality or increase anticipated costs.

Depending upon the project, the client, and available financial resources, the anticipated cost may be more or less important than the quantity and quality. The client who wishes to build a luxury residence may be willing to pay more if he can get exactly what he wants. Another may prefer to cut quantity or quality in order to bring the cost down. For the purposes of this Article, when costs are more important than quantity and quality, any cost figures that are discussed will be considered a fixed cost limitation. ${ }^{2}$ For the purposes of this Article, when quantity and quality are more important than cost, any figures discussed will be considered a cost budget. ${ }^{3}$ In many situations it is not easy to determine whether the cost figures discussed are soft as in a cost budget, or hard as in a fixed cost limitation. It should also be noted that there may have to be compromises between quantity and quality. In commercial construction, the quantity of usable space may be more important than the quality of the project. On the other hand, in other types of construction the quality of the project may be more important than the quantity. Cost considerations may dictate that space be scaled down in order to keep quality constant.

Once the client decides to retain a particular architect, the architect's function is to develop a design solution which will achieve the client's goals. To accomplish this, it is necessary for the architect and client to work together. The architect's function is to take the general needs and wants of the client and convert them to a design solution expressed in the plans and specifications. To do this, he prepares 
schematic designs, which represent a skeletal design solution, and then the design development, a more detailed design solution. These two phases of the architect's performance have been known in the past as and still are sometimes called the preliminary studies. ${ }^{4}$

After the design development or preliminary studies are approved by the client, the architect proceeds to draft the construction documents, or working drawings. These are more detailed and technical in nature. ${ }^{3}$ Their primary function is to provide prospective bidders with bidding information upon which they can base their proposals. They will comprise a major part of the successful bidder's contractual obligation.

In preliminary discussions with the prospective or "tied-down" client the architect will usually try to predict anticipated costs. The purpose of the initial cost prediction should be to determine whether it is possible to achieve the client's objectives within the client's financial desires. Such early cost predictions are usually based upon projected volume or area. In some work, the prediction can be based upon functional units such as classroom seats or hospital beds. The projected volume or area is multiplied by some area or volume figure to achieve a projected cost. ${ }^{6}$ This multiple may be based upon past experience or industry or professional data. Where the architect is inexperienced or a new type of construction is contemplated, this figure is largely guesswork.

As the architect works out his design solution to the client's design problem, he should be considering what the design solution will cost. Decisions as to design, execution, materials, and equipment often change projected costs. As details are worked out, it is easier to make a more accurate cost prediction. However, during the schematic design and development phases, many of the precise details are still not worked out. When sufficient details are workęd out, a prediction can be based upon a more precise calculation of the cost of material and the labor needed for the project. The principal methods are quantity and cost and in place unit costs. ${ }^{7}$ These methods are more accurate than the volume or area

4See American Institute of ARchitects, Handbook of Architectural Practice $\S$ III 2.03 (8th ed. 1958) [hereinafter cited as ARCHItectural HaNDBOOK].

sId. $\$ \S$ III 4.01-.09.

${ }^{6} I d$. $\$ \S$ III 3.01-.02. For a discussion of these rough methods see CREATIVE CONTROL of Building Costs 92-118 (W. Hunt ed. 1967).

'Unit costs are described as follows:

"The unit costs are the total costs for all materials and labor, including an allowance for overhead and profit, of units of construction, such as a square foot of wall or floor, or a complete door or window or other construction component." ARCHITECTURAL HANDBOOK, supra note 4, § 1113.05 .

The quantity and cost method is more commonly employed. It is described as follows:

"Quantities are surveyed (or taken off) in material units, such as thousands of brick, cubic yards 
techniques used earlier in the architect's performance, but even these methods cannot consider all the contingencies which go toward making up a construction bid.

The prime contractor has many advantages in making his bid that are not available to the architect. The contractor can use specialized bidding expertise of subcontractors whose binding bids are used to compute the prime contractor's bid. Contractors can take into account more recent data on the pricing of labor, materials, and equipment than the architect used in making cost predictions. He will also be able to take into account how busy he is, a factor which often determines his bid price. Even with these advantages, along with extensive cost records on past comparable work and experienced cost estimators, contractor bids vary considerably.

Two other aspects of architectural performance should be considered. First, the client usually must approve the work of any prior phase before the architect proceeds to the next. ${ }^{8}$ Generally, the submission for client approval includes the most recent price estimate. If the client does not approve the work submitted to him, changes in the design solution will be made by the architect. If the change covers prior approved work, the architect should be entitled to the cost of redesign. ${ }^{9}$ If the work has not yet been approved, the cost of redesign will generally be borne by the architect.

Second, the typical method of compensating the architect for his services is to multiply the construction cost by a stated percentage. ${ }^{10}$ Since performance by the architect usually spans a lengthy period of time, provisions are usually made for interim fee payments. "ln the 1966 American Institute of Architects (AlA) standard form contract, the architect is to receive five percent of his fee upon execution of the contract $^{12}$ and upon completion for various performance phases is to be paid in addition:

of sand, or board feet of lumber. . . . Labor is computed in hours and wage rates. . . The sum of all material and labor costs is the contractor's direct cost, to which must be added the project overhead .... Finally allowance must be made for general office overhead . . . To the final contractor's cost is added his anticipated profit." Id. See also Kassabaum, Methods for Control of Building Costs, in Creative Control of Building Costs 83-89 (W. Hunt ed. 1967).

'American Instrtute of Architects, Ala Doc. B131, Standard Form of Agreement between OWNer and ARchitect on a Basis of a Percentage of Construction Cost $\$ 1.1 .4$, I.1.6, 1.1.9 (1966) (on file with the California Law Review) [hereinafter cited as STANDARD FORM 1966].

${ }^{9} I d . \$ 1.3 .5$.

${ }^{10}$ ARChItectural HaNDBOoK, supra note $4, \S$ I 4.01.

"STANDARD FORM 1966, supra note 8, art. 6. Earlier terms also provided for interim fee payments. AIA Doc. B131, art. 8 (1963); AIA Doc. B131, VI (1961); AlA Doc. Bl01 15 (1958).

12STANDARD FORM 1966, supra note 8, § 6.1.1. 


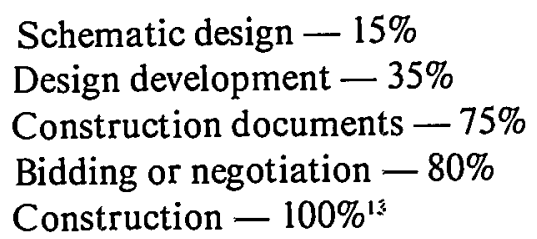

While he is performing a phase, he generally is paid on a monthly basis for the work performed in the previous month based upon the proportion of the work performed in the month to the total amount of work to be performed for the whole phase. ${ }^{14}$

After approval of the construction documents, invited contractors are given copies of them to use in making their construction bids. The crisis usually arises when the lowest bid substantially exceeds anticipated costs.

Assume that the final projected cost for the project is one million dollars. Earlier predictions may have been more or less than this figure, although predictions usually increase as the work progresses. Assume that the lowest bid among the five bidding contractors is 1.3 million dollars. The client may decide to go ahead and construct the project anyway.

However, he may decide the project is not economically feasible at that cost. The architect may offer to redesign at his own expense, but this may not satisfy the client. The client may inform the architect that he has decided not to proceed with the project. Perhaps he will pay the architect for the services he has performed. On many occasions the client will claim he is not obligated to pay because of an agreement or understanding that he would not have to pay for architectural services if the project he wanted could not be achieved within a designated cost. The client contends that his obligation to pay for architectural services was conditioned upon the project being built for around one million dollars. He then is asserting that the cost figure is a cost condition.

The architect may deny any such agreement. He may point to provisions in a written contract executed by himself and his client which do not include any such agreement and which may, in fact, disclaim such agreement. He may point to language which states that he is to be paid if for any reason the project is abandoned. The architect usually states that he has no control over those variables which make up construction costs. He may state that he normally does not assume the risk that he would be unpaid for services he has rendered and did not assume it in this case. $\mathrm{He}$ may be willing to concede that he should not recover if it can be shown

${ }^{13} I d . \S 6.1 .2$.

"Id. \$6.2. 
that his cost predictions were made negligently. But he does not feel that he should suffer a forfeiture if his cost estimate, however reasonably made, turned out to be inaccurate. In rebuttal, the client may contend that it makes no sense for him to have to pay for plans which turn out to be useless to him.

From a legal standpoint a number of issues emerge in such a dispute. What evidence can be examined to determine what the contractual obligations were between the architect and his client? Since the client frequently asserts an oral agreement between himself and the architect under which he would not have to pay, the parol evidence rule may be invoked by the architect.

Another question relates to the right of the architect to redesign the project so as to make it come within any cost prediction figure. The architect may assert the right to "cheapen" the project in order to cut down the costs. He may also request that the client cooperate with him by reducing the quantity and quality or increasing the cost figure. The client may resist these demands and state that there is nothing in the contract which gives the architect this right or imposes any obligation upon the client. If such provisions are found in the contract, the client may assert that he did not see them and that they were not pointed out or explained to him by the architect. ${ }^{15}$ He may state that he does not want a cheapened project. He may contend that he expected a structure of a certain quantity and quality at a designated price. If he cannot get this, he does not wish to proceed, and he feels that he should not have to pay for architectural services.

While the architect may admit or deny the creation of any cost condition, he may nevertheless assert that any cost condition created was excused because of the client's conduct or statements.

THE LAW

\section{A. Judicial Lawmaking: A Look at the Decisions}

\section{Promises and Conditions}

An architect may promise the client that the contractors' bids will be within a cost figure set by the client. If this event-the bids being within the figure-does not occur, the architect may be liable for any damages suffered by the client because of delay or rising costs during redesign.

To obtain a commission, the architect might agree to risk his fee on

${ }^{15}$ Spitz v. Brickhouse, 3 1ll. App. 2d 536, 123 N.E.2d 117 (1954). 
the accuracy of his cost estimates. If so, a condition has been established concerning the client's obligation to pay. First the contractors' bids must be received, showing the accuracy of the architect's estimates. Only then, under the agreement as stated above, would the client have a duty to pay the architect's fee.

Cost problems usually involve a determination of the exact nature of the architect's promise with regard to costs and of the exact nature of the event which must occur or be excused before the client is obligated to pay a fee. The exact nature of the architect's promise first depends on what assurance he has given the client, orally or in writing. Next, it will depend on the nature of the promises that are implied, rather than expressed. Promises may be implied from surrounding circumstances, custom, trade usage, and implied by law. The architect may have promised: (1) To use due care; (2) to be accurate; and (3) that the project cost would not exceed a particular amount. If the architect has promised to be accurate, normally the reason for inaccuracy is not relevant. In effect, he has guaranteed the accuracy of his estimate. If he is not correct, he has breached and is liable for any foreseeable damage caused by the breach. ${ }^{16}$

The exact nature of the event that conditions the client's obligation to pay the fee depends upon the agreement, surrounding facts and circumstances, and the application of the legal doctrine of conditions. The event might be: (1) Use of due care in preparing architectural cost estimates; ${ }^{17}(2)$ the project cost not exceeding a specified amount or the final cost estimate; ${ }^{18}$ (3) the client being satisfied with the bids (or bidders) $;{ }^{19}$ (4) the availability of adequate funds, ${ }^{20}$ and (5) the project being built. ${ }^{21}$

A promise can be, and often is, a condition. The architect might promise to use due care, and the exercise of due care could also condition the client's obligation to pay the fee. The architect might promise to be accurate, as well as condition his fee upon the accuracy of his cost estimate. ${ }^{22}$ In the latter case, the architect's inaccuracy would cost him his fee and he could also be liable for damages for breach.

${ }^{16}$ Capitol Hotel Co. v. Rittenberry, 16 Tex. Civ. App. 477, 41 S.W.2d 697 (1931).

'Pieri v. Rosebrook, 128 Cal. App. 2d 250, 275 P.2d 67 (1954); Moneypenny v. Hartland, 171 Eng. Rep. 1227 (K. B. 1824), affd 172 Eng. Rep. 171 (C.P. 1826).

"Feltham v. Sharp, 99 Ga. 260, 25 S.E. 619 (1896); Wilson v. Ward, 14 B.C. 131 (1908).

${ }^{19}$ Pack v. Wines, 44 Utah 427, 141 P. 105 (1914).

${ }^{20}$ See Rosenheim v. Howze, 179 Cal. 309, 176 P. 456 (1918).

"Rowell v. Crow, 93 Cal. App. 2d 500, 209 P.2d 149 (1949); Loyal Order of Moose v. Faulhaber, 327 Mich. 244, 41 N.W.2d 535 (1950); cf. Hewitt v. Webb, 253 Pa. 406, 98 A. 609 (1916).

${ }^{22}$ Hite v. Aydlett, 192 N.C. 166, 134 S.E. 419 (1926). However, some courts will grant recovery in quantum meruit even where the owner does not use the plans. White v. Kanrich, 201 Cal. App. 2d 356, 20 Cal. Rptr. 37 (1962) 
The promise and the condition need not be identical. The architect might promise to use due care, and yet, by agreement, his fee could be conditioned upon the accuracy of his estimate, the bids being acceptable, or the project being built. He might promise to be accurate, but the agreement might condition his right to receive his fee upon the use of due care. In the latter case, his inaccuracy would not cost him his fee if he used due care, but he would be liable for damages.

\section{Agreement on Costs}

In the typical dispute over excessive costs, client and architect usually agree that costs were discussed both before and during the architect's performance. Usually both parties agree upon the amount of the projected cost. They may even agree that the cost figure was "firm," or that a fixed cost limitation was created. The focus of disputes concern the architect's right to be paid when the project is given up because the objectives of the client could not be attained within the specified cost figure. The client states that he had been assured that, if the project could not be brought in within the specified amount, he would not be obligated to pay the architect's fees. The architect usually denies any agreement to that effect and points to the absence of such a provision from the writing, or even to a written disclaimer which he claims negates any such understanding. The two principal legal issues relevant to the resolution of the question of whether a cost condition has been created are:

1. Does the execution of a written agreement that does not contain a cost condition preclude the client from testifying about the asserted agreement?

2. What factors are relevant in the determination of whether such an agreement took place?

Most of the cost condition cases have involved the issue of whether the client will be permitted to testify about the asserted oral agreement relieving the client from obligation to pay if the project could not be brought within a specified cost-condition figure. The courts' resolution of this issue has involved the parol evidence rule. Some courts phrase the rule as one which rejects evidence of prior oral agreements because such evidence would "vary, add to, or contradict" a subsequent written agreement. ${ }^{23}$ Other courts articulate the rule as one which deals with the presumptive completeness of writings. ${ }^{24}$ Still other courts speak of the necessity of using all available evidence to determine whether the parties

${ }^{23}$ See, e.g., Walker v. Horne, 149 F. Supp. 457 (W.D.N.C. 1957); Miami Pet. Co. v. Neal, 333 S.W.2d 876 (Tex. Civ. App. 1960).

'See, e.g., Seitz v. Brewers' Refrig. Co., 141 U.S. 510 (1891); Neal v. Marrone, 239 N.C. 73, 79 S.E.2d 239 (1953). 
intended to integrate their entire agreement in one final and complete writing. ${ }^{25}$ These variant approaches have caused confusion and have made the application of the rule most uncertain.

Prediction concerning the admissibility of testimony about an alleged prior or contemporaneous oral agreement on costs is hazardous, because of the differing attitudes toward the rule from state to state, and even within a given state. ${ }^{26}$ Nevertheless, certain generalizations can be extrapolated from a reading of the many decisions which have involved architect-client contracts.

If the agreement is silent on the question of costs or fixed cost limitations, it is likely that the client will be permitted to testify on the alleged agreement. ${ }^{27}$ There have been a few cases to the contrary, usually where the contract has mentioned cost estimates in some way. ${ }^{28}$ However, most courts assume that costs are discussed by the parties in every case. If the writing makes no mention of any understanding on costs, these courts assume that the writing is not complete. ${ }^{29}$

Prediction on admissibility of evidence of prior oral agreements relating to costs is more difficult if there is language in the writing which deals in one way or another with this question. Prior to 1961, the standard AIA contract stated that the architect did not guarantee estimates. A number of cases have involved this clause, and the results illustrate the difficulty of predicting the success of this disclaimer, as well as disclaimers generally..$^{30}$

A case before the Wisconsin supreme court in 1944 involved a written contract executed after the completion and approval of preliminaries. ${ }^{31}$ The court held that the trial court had committed error when it permitted the client to testify about an understanding on

${ }^{2 s}$ Spitz v. Brickhouse, 3 11l. App. 2d 536, 123 N.E.2d 117 (1954); Rosenthal v. Gauthier, 224 La. 341, 69 So. 2 d 367 (1953); Wetzel v. Roberts, 296 Mich. 114, 295 N.W. 580 (1941); Levy v. Leaseway System, Inc., $190 \mathrm{~Pa}$. Super. 482, 154 A.2d 314 (1959). Another approach was used by the court in Spurgeon v. Buchter, 192 Cal. App. 2d 198, 13 Cal. Rptr. 354 (1961). The oral contract was reduced to a writing. No cost condition was mentioned in the vriting. The court found that the contract was complete, but found that a consistent collateral contract on cost condition existed and denied the architect recovery of his fees on the contract or in quantum meruit.

${ }^{26}$ See Sweet, Contract Making and Parol Evidence: Diagnosis and Treatment of a Sick Rule. 53 CORN. L. REv. 1036 (1968).

${ }^{27}$ See, e.g., Almand v. Alexander, 180 Ark. 947, 951, 23 S.W. 2d 6I1, 612 (1930); Bair v. School Dist. No. 141, 94 Kan. 144, 146 P. 347 (1915).

${ }^{28}$ See, e.g., Baylor Univ. v. Carlander, 316 S.w.2d 277 (Tex. Civ. App. 1958).

${ }^{29}$ See Hudson v. Barneson, 41 Cal. App. 633, 183 P. 294 (1919); Petrus v. Bunnell, 129 So. 2d 702 (Fla. Dist. Ct. App. 1961); Keene v. Farris, 67 S.W.2d 526 (Kansas City, Mo. Ct. App. 1933); Hite v. Aydlett, 192 N.C. 166, 134 S.E. 419 (1926); Svarz v. Dunlap, I34 Wash. 555, 235 P. 801 (1925).

${ }^{30}$ Compare Wick v. Murphy, 237 Minn. 447, 54 N.W.2d 805 (1952), with Spaulding v. Partiridge, 28 Cal. App. 2d 658, 83 P.2d 80 (1938).

${ }^{3}$ Mitterhausen v. South Wis. Conference Ass'n, 245 Wis. 353, 14 N.W.2d 19 (1944). 
excessive costs. The court stressed that when the contract was signed, a good deal of the detail had been worked out. The court held the written contract to be complete.

An Illinois decision in 1954 involved the identical clause. ${ }^{32}$ The court distinguished this case from the Wisconsin case on the basis of when the contract was executed. In the Illinois case, the contract was signed before there had been any agreement on details and before the architect had started his work. The court also emphasized that the client had not read the agreement and that it had been pulled from the architect's drawer with a casual remark by the architect that the agreement merely precluded the client from changing architects.

In a later case, the Texas Court of Civil Appeals attempted to reconcile the two earlier decisions. ${ }^{33}$ The court held that a writing executed after preliminaries are approved is complete, since the client can no longer make major changes. Since the writing was complete, evidence of an alleged oral agreement would not be received by the court.

From the standpoint of the architect, a synthesis of these three cases is not very encouraging. The architect normally wants, and is encouraged, to obtain a written agreement with the client as soon as possible. If the agreement is signed before completion of preliminaries, the pre-1961 disclaimer will not be of much use in avoiding testimony by the client about an alleged prior oral agreement on costs. Subsequent AlA contracts are more complete and are reasonably well drafted. They may do better in the courts than did their predecessors even though subjected to a test of completeness based upon when the contract is executed.

Nevertheless, there is always a risk that, when the client's expectations differ from the contract, the courts will interpret the clause narrowly. Even well-drawn clauses can be attacked by assertion of fraud or mistake, by a request that the writing be reformed because it did not correctly express the true understanding of the parties, or by a claim that the agreement was made after formation of the contract and thus not affected by the parol evidence rule. The oral agreement is used to interpret the writing if the contract does not explicitly state that the client need not pay if the costs are too high. No contractual provision, however well drawn, will ensure that the client will not be able to bring his contention before the judge and jury.

The courts have looked at factors other than the written or asserted oral agreement in resolving the question of the creation of the cost

\footnotetext{
${ }^{32}$ Spitz v. Brickhouse, 3 Ill. App. 2d 536, I23 N.E.2d 117 (1954).

"Baylor Univ. v. Carlander, 316 S.W.2d 277 (Tex. Civ. App. 1958).
} 
condition. Even if the client's testimony is received into evidence, the question of determining whether the agreement did take place as alleged must be resolved by the court or jury. Courts have admitted evidence of custom in the profession. Architects have been permitted to introduce evidence that customarily architects do not assume the risk of the accuracy of their cost predictions. ${ }^{34}$ Also, courts have been more favorably disposed toward holding for the architect if the project in question has involved remodeling rather than new construction, because estimating costs in remodeling is extremely difficult. ${ }^{35}$ The same result should follow if the type of construction involves experimental techniques or materials.

Courts sometimes distinguish between cases and justify varying results on the basis of the amount of detail given to the architect by the client in advance. ${ }^{36}$ Generally, the greater the detail, the easier it should be for the architect to predict accurately. However, it is much more difficult for the architect to fulfill the desires of the client within a specified cost figure if the chient retains a great deal of control over details, especially if these controls are exercised throughout the architect's performance. For this reason, some courts have held that a cost condition is not created where the architect is not given much flexibility in designs or materials. ${ }^{37}$

Sonie courts have looked at the stage of the architect's performance in which the cost condition was created. ${ }^{38}$ If it is created at an early stage, it is more difficult for the architect to be accurate in his cost predictions. Generally, the later the cost limit is imposed in good faith, the more likely it is to be a cost condition. ${ }^{39}$ But courts should recognize that if it is imposed later, creation-or, more realistically, impositionmay be an unfair attempt by the client to deprive the architect of his fee.

Occasionally the courts have applied the rule that an ambiguous contract should be interpreted against the person who drew it up and thus created the ambiguity..$^{40}$ If the client is a private party, the contract is usually drafted or supplied by the architect. Courts have looked at the

${ }^{34}$ Douglas v. Rogers, 10 Ga. App. 486, 73 S.E. 700 (1912).

${ }^{35}$ See Nolan v. Perloff, 10 La. App. 618, 622, 119 So. 754, 756 (1929).

${ }^{36}$ See cases cited note 37 infra.

${ }^{3}$ See Bueche v. Eickenroht, 220 S.W.2d 911 (Tex. Civ. App. 1949); Schwender v. Schrafft, 246 Mass. 543, 141 N.E. 511 (1923).

${ }^{38}$ Texas Delta Upsilon Found. v. Fehr, 307 S.W.2d 124, 131 (Tex. Civ. App. 1957); Mitterhausen v. South Wis. Conference Ass'n, 245 Wis. 353, 14 N.W.2d 19 (1944).

${ }^{39}$ See Pack v. Wines, 44 Utah 427, 141 P. 105 (1914) (no recovery of fees for architect where cost limit set after contract executed and cost limit excecded).

${ }^{40}$ See, e.g.. Wick v. Murphy, 237 Minn. 447, 453, 54 N.W.2d 805, 809 (1952). 
building and business experience of the client.41 If the client is experienced, he should be more aware of the difficulty of making accurate cost estimates. If he has building experience, the client is more likely to be aware of the custom that architects usually do not risk their fee upon the accuracy of their cost estimates.

Courts have sometimes cited provisions for interim payments as an indication that the architect is not assuming the risk of losing his fees on the accuracy of his cost estimates. ${ }^{42}$ However, standard printed clauses buried in a contract are not always an accurate reflection of the understanding of the party not familiar with the customs or the forms. If payments have actually been made during the architect's performance, this is a clearer indication that the client is not laboring under the belief that he will not have to pay any fee if the low bid substantially exceeds the final cost estimate..$^{43} \mathrm{~A}$ few cases have looked for good faith on the part of the client. ${ }^{44}$ For example, if the client has offered some payment to the architect for his services, this may impress a court as a show of fairness and good faith.

On the whole, architects have not fared well in court. Courts often assume that a fixed cost limitation means a cost condition. ${ }^{45}$ Such decisions do not draw a line between permission for the client to terminate the arrangement if costs are too high and agreements under which the architect would go uncompensated for services which may prove to have little or no value to the client.

\section{Interpretation}

If it is established that a cost condition has been created, the next issue is that of interpretation. What is necessary to satisfy the cost condition? The architect is permitted some margin of error. Courts have adopted a test which employs a type of substantial performance. ${ }^{46}$ Many architects suggest, and often contracts permit, a deviation of ten percent.

"See Zannoth v. Booth Radio Stations, Inc., 333 Mich. 233, 52 N.W.2d 678 (1952). (1922).

${ }^{42}$ See Robb v. Sherrill-Russell Lumber Co., 194 Ky. App. 835, 838-39, 241 S.W.64, 65-66

${ }^{43}$ See White v. Kanrich, 201 Cal. App. 2d 356, 20 Cal. Rptr. 37 (1962).

${ }^{4}$ See, e.g., Pack v. Wines, 44 Utah 427, 141 P. 105 (1914).

4s See, e.g., Rowell v. Crow, 93 Cal. App. 2d 500, 209 P.2d 149 (1949); Eberhard v. Mehlman, 60 A.2d 540 (D.C. Mun. App. 1948); Ada Street Methodist Episcopal Church v. Garnsey, 66 IIl. 132 (1872).

${ }^{46}$ See Brinckle v. England, 25 Del. 16, 78 A. 638 (Super. Ct. New Castle County 1910) (cost ceiling must be substantially exceeded to provide defense to owner in action by architeet for fees); Andry \& Feitel v. Ewing, I5 La. App. 272, 130 So. 570, 572 (1930) (judgement for owner, holding that where cost ceiling was $\$ 12,000$ and bids ranged from $\$ 18,000-21,000$, they were "materially in excess of the amount fixed"); Willar v. Nagle, 109 Md. 75, 80, 71 A. 427, 429 (1908) (limit of $\$ 90,000$, bids were $\$ 125,000$; proper for judge to find breach of cost condition as a matter of law); 
The cost figure which determines the occurrence of the condition is usually the construction bid submitted by the contractor. ${ }^{47}$ Normally cost of acquiring the land, consultants' fees, and fees of the architect are not considered costs for this purpose. ${ }^{48}$

Sometimes ultimate costs exceed the low bid because of extra work or because unforeseen circumstances develop in performance which lead to the contractor being given an increase in the contract price. ${ }^{49}$ The cost of extra work should not bear upon the cost condition unless the extra work is needed to compensate for design errors of the architect. An illustration of unforeseen circumstances would be the discovery of unexpected subsoil conditions, which could lead to a price increase. This should have no bearing upon the cost condition.

To sum up, in the normal situation, the condition has occurred if a low, enforceable bid is received which is reasonably close to the costcondition figure.

\section{Implication of Terms-Redesign}

In addition to determining what the parties have expressly agreed to, courts are often called upon to fill in contractual gaps which either were not considered by the parties or were terms which they believed to be so obvious that contractual expression was unnecessary. As a rule, courts are hesitant to imply terms. They will do so if firmly convinced that: (1) Had the question been called to the attention of the parties at the time the contract was made, the parties would have agreed to this interpretation; or (2) without implication, the object of one or both of the contracting parties would be drastically frustrated; or (3) implication is needed to make a binding contract when the parties intended to be bound; or (4) in extreme cases, an implication of terms is demanded by basic notions of fairness and good sense..$^{50}$

Implication of terms is important in relation to the problems of redesign by the architect and cooperation by the client in reducing costs. If all the bids are too high, does the architect have a right to redesign in order to meet the cost condition? The first consideration must be that of the contract terms. However, even if there is no contractual provision providing for a right to redesign, the architect should be given this

Smith v. Dickey, 74 Tex. 61, 11 S.W. 1049 (1889)(estimated cost of $\$ 100,000$; held bid of $\$ 107,000$ was substantial compliance with cost condition).

${ }^{47}$ Cf. Bissell v. McCormack, 162 Wash. 482, 298 P. 697 (1931).

${ }^{43}$ See Miller v. Brown, 136 Cal. App. 2d 763, 289 P.2d 572 (1955).

${ }^{*}$ See, e.g., Hutchinson v. Conway, 34 N.S. 554 (1901) (increased cost of materials, additions by owner to original specifications).

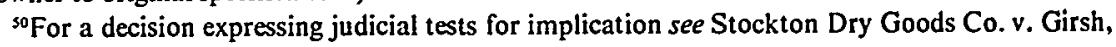
36 Cal. 2d 677, 227 P.2d 1 (195I). 
opportunity. ${ }^{51}$ The arrangement between architect and client is a professional relationship, where both parties should do their utmost to accomplish the goals of both. Frequently, redesign can avoid forfeiture of the architect's fee.

Cooperation by the architect should also be required. The client should not be expected to agree to a material change of the design solution agreed to earlier by architect and client. The client should not have to go farther than agreeing to cheapening of the work. The basic design should continue, but the changes should relate to reducing the cost without affecting the utility and purpose of the project.

Since 1961 AIA contracts give the architect a right to redesign, require the client to cooperate, and, in addition, require the client to increase his cost limit..$^{52}$ This is going rather far. It is most unlikely that a court would imply this, in addition to the right to redesign and cooperation.

There are limits to the right to redesign. If the delay inherent in redesign would work a material hardship on the client, the architect should not be given the opportunity to redesign. Also, if the variance between the low bid and the cost condition is so extreme that it appears unlikely that redesign will be successful, then the architect should not have the right to redesign.

Should the law imply a promise by the architect that he will redesign if the client so wishes? If a cost condition is created, and the architect does not want to redesign, he should not be required to do so. He has already lost his fee, and it would be unfair to require him to try to bring the project within the cost condition if he does not think it feasible. The implication of such a promise would be a type of compulsion hardly suitable to the architect-client professional relationship. Even if there is no cost condition, it is unlikely that the law would or should require redesign. Usually, the architect does not promise to bring the project in at a specified cost.

\section{Condition Excused}

The duty to perform a promise does not arise until events which condition performance either occur or are excused. Excuse can be divided into a number of related, but analytically different, concepts. These are prevention, hindrance, lack of cooperation, estoppel, waiver, and impossibility. Courts have not always respected the analytical distinctions. They often use waiver to include almost any type of

'See Nolan v. Great S. Wirebound Co., 12 La. App. 608, 127 So. 98 (1930).

s2AIA Doc. B131, IV-5 (1961); AIA Doc. B131, Art. 6.5 (1963); AIA Doc. B131, Art. 3.5.1 (1966). 
situation which excuses the condition. However, definition of these concepts should facilitate a better understanding of the basic concept of excuse of conditions.

(a) Prevention, Hindrance, or Lack of Cooperation.-If the client unjustifiably prevents the cost condition from occurring, hinders the occurrence of the condition, or fails to take reasonable, positive action which would cause the condition to occur, the condition is excused and the promise matures. The client should not be permitted to set up the failure of the condition to occur as a defense under these circumstances.

A refusal by the client to discuss the project or to furnish necessary information would excuse the cost condition. This would be a clear case of lack of cooperation. The same result would follow if the client refused to discuss the architect's solution or to consider approval of the plans. ${ }^{33}$

Excessive changes ordered by the client during design phases would be prevention, since the architect normally must comply with clientdirected changes. ${ }^{54}$ However, if the changes were necessary to compensate for design errors or omissions, or if the architect did not inform the client of the effect the changes would have on costs (and the client was not made aware of the effect of increased costs due to changes from some other source of information) then the changes should not excuse the condition.

Prevention can arise during the bidding phase. If the client refuses to submit invitations to any bidders or to attempt to negotiate a contract, the condition would be excused.

The client could prove to be so difficult to deal with during the prebid period, or during the bid negotiations, that he would be unable to find a contractor willing to enter into a contract with him. Some client irascibility may be expected when the architect agrees to work with a particular client, but if the irascibility is motivated solely by a desire to avoid a fee, the cost condition should be excused.

What if the client refuses to use a representative group of bidders? ${ }^{\text {ss }}$

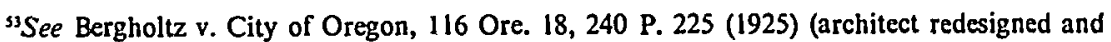
secured contractor at owner's request, and owner then rejected plans; architect allowed to recover fees).

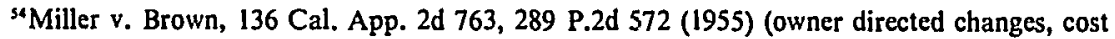
limitation excused); Marten v. McMahon, 95 Cal. App. 75, 271 P. 1114 (1928); Harrison v. McLaughlin Bros., $108 \mathrm{Md}$. 427, 70 A. 424 (1908) (architect held entitled to fees for full cost of project where owner's changes resulted in project exceeding cost limitation); Blackhall v. DuthieStrachan, 258 Mass. 551, 125 N.E. 604 (1927) (many owner-directed changes excused cost condition).

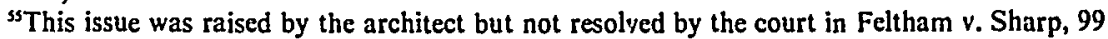
Ga. 260, 25 S.E. 619 (1896). The architect sought to have the owner open the project to public bids rather than obtain estimates solely from two local bidders. 
What if the client refuses to permit a particular contractor to bid, or refuses to negotiate with a reputable contractor who is willing to do the work within the cost condition amount? Clearly the condition should be excused in those cases where the client's principal motive is to avoid paying the architect his fee. Even if the client has an honest reason for his refusal, the condition should be excused. The architect should not have to take the risk that only a bid by a contractor satisfactory to the client will satisfy the condition, unless the contract so specifies. The client cannot be compelled to enter into a contract with a builder against his will, but his failure to do so may constitute lack of cooperation and excuse the cost condition.

A low bid may be received within the cost-condition amount, but the bidder may ask to be released from his bid because of an alleged computation error or because of the omission of a key cost item from his bid computation. There is a current trend toward granting relief in such cases.$^{56} \mathrm{~A}$ judicial determination relieving the contractor from his bid would mean that the condition has not occurred. Occurrence of the condition requires a judicially enforceable bid within the cost figure. The condition should not be excused if the release is based upon the honest belief of the client, or on a legal opinion of his attorney, that the bidder would be able to obtain judicial relief. The client should not be compelled to go to court to avoid excusing the cost condition.

What if the client releases the bidder, not because of belief or advice that the bidder could obtain judicial relief, but because of the client's honest belief that it would be inequitable to compel the bidder to stick to his bid or a belief that a dissatisfied bidder will not do a good job? Conceding the honesty and soundness of the client's judgment, the condition should be excused in such a case. The client may release the bidder, but the cost condition has been excused, and the architect is entitled to his fee. ${ }^{57}$

Even if there is prevention, hindrance, or lack of cooperation, the condition analytically should not be excused unless the architect can show, with reasonable certainty, that the cost condition would have occurred had it not been prevented or hindered, or had there been cooperation. ${ }^{58}$ When courts want to overlook this requirement, they often use waiver. This, as will be seen, does not require a showing that the condition would have occurred. In any case, judicial inquiry into probability

${ }^{56} \mathrm{See} 3$ A. Corbin, Contracts $\S 609$ (1960).

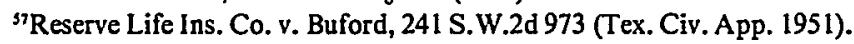

stSee generally 5 S. Williston, ConTRACTs 677 (3d ed. Jaeger 1961). 
of occurrence is likely to be perfunctory if the conduct, or failure to act, by the client seems motivated by bad faith..$^{99}$

(b) Estoppel.-Estoppel is based upon reliance or change of position. When one party has indicated he does not intend to enforce a provision in his favor and the other party relies upon this and fails to take steps that would make the condition occur, the condition cannot later be asserted as a defense.

In the architect-client context, estoppel would result if the client, either by words or acts, led the architect to believe the cost condition would not be enforced by the client, and the architect failed to take steps which he could have taken to bring the costs within the amount established by the cost condition. To illustrate, estoppel might result if the client tells the architect he is so pleased with the design that he does not care about the cost. If the architect then proceeded with the design, when he could have changed the design and caused the condition to occur, the client would be estopped from asserting the condition, and the condition would be excused.

Approval of the preliminaries or construction documents may cause the architect not to make design changes which would have brought the costs within the cost-condition amount. However, estoppel would arise only if the approval were given with knowledge that the cost would exceed the cost-condition figures. ${ }^{60}$ Normally, this knowledge would come from a revised cost estimate given by the architect, although the client could become aware of the effect on costs in some other way. Reliance by the architect, without such knowledge on the part of the client, would not be reasonable. If so, there would be no estoppel to prevent the client from asserting the cost condition as a defense to an action by the architect to collect his fee.

What if approval of the plans were accompanied by a statement by the client that he still wanted to stand upon the cost condition, but that he could not take the time to wait for the architect to redesign? If the time pressure is the result of unexcused delays of the architect, the condition should not be excused. If the client proceeds to use the plans, he will have to pay for their use. In such a case, the architect's right to payment would not be based on the contract, since the cost condition has neither occurred nor been excused. Recovery would be based upon the doctrine of quasi-contract, predicated upon unjust enrichment. ${ }^{61}$ If the

${ }^{99}$ See Cann v. Rector, 111 Mo. App. 164, 85 S.W. 994 (1905) (rejection of plans must be in good faith).

${ }^{\circ 0}$ See Hall v. Parry, 55 Tex. Civ. App. 40, 118 S.W. 561 (1909).

${ }^{6}$ See Arata v. Sunseri, 147 So. 2d 222 (La. Cl. App. 1962); Bissell v. McCormack, 162 Wash. 482, 298 P. 697 (1931) (use of plans by owner created an implied contract to pay reasonable value of plans and specifications). 
time pressure is not the fault of the architect, and he could have satisfied the condition by redesign, there is detrimental reliance. The cost condition is excused, and the promise to pay the architect's fee enforced.

What if the client is informed of the excessive cost estimate but decides to submit the plans to bid because he believes the architect is too conservative? If the bids are too high, the architect should be given a right to redesign. In addition, any additional costs due to the delay in redesign should be charged to the client. If redesign is no longer feasible, the condition should be excused if redesign earlier could have caused the condition to occur.

Sometimes estoppel may be based upon interim fee payments made by the client despite his awareness that the cost would be likely to exceed the cost-condition figure. This knowledge may come from higher cost estimates given by the architect, or from other sources of information. In such a case, the architect may reasonably be led to believe that the client no longer intends to enforce the original cost condition. If the architect has relied on this as reason for not redesigning, the condition should be excused.

Estoppel could also arise if the client used the plans, despite knowledge of the excessive cost. ${ }^{62}$ Here, the client's knowledge is usually easy to establish, since the use usually occurs after the bids are in.$^{63}$ If the client let the contract rather than permitting the architect to redesign, and if this was due to inadequate time for redesign, the question of estoppel would depend upon the reason for the time pressure. If the fault was that of the architect, it is probable that he has no right to redesign, and the cost condition would not be excused. Recovery in such a case would have to be based on quasi-contract or unjust enrichment.

Since quasi-contract is based upon unjust enrichment, the measure of recovery will be the benefit conferred on the client by the use of the plans. This might be measured by the reasonable value of the architect's services, a measure not too different from that of the contract remedies available to the architect had there been no cost condition. ${ }^{64}$ If the architect did not estimate very accurately, he would be likely to find that a court would hold that the benefit conferred was of a lesser value than what the architect would have received under the contract.

Note that estoppel is not based upon an actual intention on the part of the client to dispense with the cost condition. It is based upon words or acts which lead the architect so to believe, followed by detrimental reliance.

\footnotetext{
${ }^{62}$ Bissell v. McCormack, 162 Wash. 482, 298 P. 697 (1931).

${ }^{63}$ Benenato v. McDougall, 166 Cal. 405,137 P. 8 (1913).

${ }^{4}$ See Bissell v. McCormack, 162 Wash. 482, 298 P. 697 (1931).
} 
(c) Waiver.-Waiver is related to estoppel, but there is an analytical distinction not always drawn by courts. Estoppel is based upon detrimental reliance, upon the concept that, but for the act constituting the estoppel, the architect would have caused the cost condition to occur. To create a waiver, there need be no showing of reliance, or that the condition would have occurred. All that is required is evidence that the client has communicated an intention to pay the fee, despite the failure of the cost condition to occur. ${ }^{65}$ The condition was for his benefit. If he manifested an intention to give up this benefit, he should be held to his communicated intention, and the cost condition should be excused. Because of its simplicity, most of the cases have used waiver to excuse the condition. This avoids the need for going into the true elements of estoppel, which, in many cases, would be difficult for the architect to show.

Waiver is relatively easy if the intention is clearly expressed by oral or written communication. For example, if the client states that he is so pleased with the design that he does not care about costs, the condition will be waived without any need to show reliance by the architect. Even if the architect could never have met the cost condition, the waiver is likely to excuse the condition.

The most difficult aspect of this seemingly simple formula for excusing conditions is in determining what acts manifest waiver, other than express statements. Often, waiver is predicated upon acts that have been discussed-approval of plans, excessive changes, payments, or use of plans. ${ }^{66}$ Acts such as these can often have ambiguous meanings. Do they manifest an intention on the part of the client to dispense with the condition? An important element in deciding on the legal effect of these acts is awareness by the client, when the acts are performed, that costs are likely to exceed the amount of the cost condition. The architect can hardly assume that these acts manifest the requisite intent of waiver on the part of the client if the client is not aware of the likelihood of excessive costs. For this reason, as well as others, the architect must keep the client constantly informed on current cost estimates-especially after changes made by the client. If he does not, a court is less likely to hold that these acts by the client waive the condition.

If acts such as payment, changes, approval of plans, or use of plans occur, but the client makes it quite clear that he is not giving up the condition, there is no waiver. Estoppel will be difficult to find, because the statement of the client's intention to stand on the condition should

${ }^{65}$ On waiver and estoppel see 3A A. CoRBIN, Contracts $\$ \S 752-53$ (1960).

${ }^{6 S}$ See Bruno v. Gauthier, 70 So. $2 \mathrm{~d} 693$ (La. Ct. App. 1954), 
make any reliance by not redesigning unjustifiable. In such a case, the condition is still in effect. If the client has used the plans, the recovery should be predicated upon quasi-contract.

(d) Impossibility.-Architects sometimes assert that performance of the cost condition became impossible because of circumstances over which they have no control. A condition of a minor or technical nature may be excused if its occurrence has become impossible, and if the risk of impossibility has not been assumed by the promisee (in this case, the architect). Without going into the difficult question of whether a cost condition is minor or technical, the creation of a cost condition means the architect assumes the risk of most prediction factors. This includes a steep rise in wage and material costs, or volatility of the construction market, factors which help to make cost prediction difficult. ${ }^{67}$ This is one of the primary reasons for avoiding the creation of a cost condition by a clear understanding with the client and by use of an appropriate disclaimer clause in the contract.

A cataclysmic event, such as a war or great natural catastrophe, might cause a different result. ${ }^{68}$ If costs become excessive for these reasons, normally use of the plans will constitute a waiver, and the cost condition will be excused. If the plans are not used, the architect should recover if the contract provided that he would be paid if the project was abandoned for any reason. Even without such an "abandonment" clause, the condition should be excused. The architect created the design requested by the client but not at the price limit set because of extraordinary reasons beyond his control. ${ }^{69}$ Creation of a cost condition places most risks upon the architect, but not every conceivable risk.

The doctrine of excuse by impossibility has not been of much assistance to the architect. Where the question of creation of the condition is close, the decision should be resolved for the architect if the reason for the excess cost is related to unforeseeable and catastrophic circumstances.

\section{Measure of Recovery}

(a) By Architect.-If the court finds that no cost condition was created, or that if one was created, it was excused, what is the measure of the architect's recovery? This discussion assumes that the client does not permit the project to be continued.

'Issenhuth v. Independent School Dist. No. 22, 54 S.D. 50, 222 N.W. 494 (1928).

"RESTATEMENT OF CONTRACTS $\$ \$ 460-61$ (1932).

${ }^{69} \mathrm{Cf}$. Issenhuth v. Independent School Dist. No. 22, 54 S.D. 50, 222 N.W. 494 (1928); Hutchinson v. Conway, 34 N.S. 554 (1901); Grant v. DuPont, 8 B.C. 7, aff d, 8 B.C. 223 (1901). 
Under normal contract principles, the architect should be put in the position he would have been in had the contract been fully performed. This would be a protection of his expectation interest. Under this test, he would be entitled to his entire fee, based on full performance (determined by the contract rate times the estimated cost) less interim fee payments received and less the expense saved by him in not having to perform further. In addition, he would be entitled to any additional damages caused by the breach which were foreseeable at the time the contract was made.

An illustration would be commissions he might have been able to obtain had he completed the project. Perhaps he could show that other clients would have retained him, had he been able to show them the completed project, and that these clients were lost when the project was abandoned. Such evidence would not be relevant if, as in the AlA contract, the client is given the privilege of abandoning the project.

Other possible recoverable items would be losses incurred due to the need for a sudden reduction in the architect's staff or the diminished productivity of personnel especially hired for the project who could not be immediately released. The architect would have to show causation and foreseeability to recover for these losses, however, and both are usually difficult to prove.

As an alternative to expectancy, the architect might be able to recover his reliance, or out-of-pocket expenses. This would normally be the reasonable value of the architectural services performed, without regard to future services. As a rule, like most professionals, this is all the architect will try to recover.

Generally, AlA contracts permit the architect to recover the reasonable value for his services performed to date of termination plus "terminal expenses" if the project is abandoned..$^{70}$ This clause might be held to preclude his right to recover expectation damages, if it were found that the contractual measure of recovery was exclusive. No cases have discussed this question. If the architect wishes to preserve his right to expectancy damages, this clause, if used, should be amended to state that it is not the exclusive remedy.

There may be a longrun advantage to using reliance as the exclusive remedy. Such a remedy emphasizes the professional nature of the architect-client relationship. Emphasis upon this might convince the court that a cost condition was not created, since the limited remedy and professional relationship are incompatible with the creation of a cost condition. This factor could be influential in close cases, leading a court 
to exclude evidence of a cost condition or to hold that no condition was imposed.

Interim fee payments raise the problem of divisibility. These payments, like progress payments to contractors, are not based upon precise value measurements, nor upon agreed valuations of the architect's services at the various stages of his performance. The payments are rough approximations, intended to give the architect operating funds during his often lengthy performance. When the architect sues to recover the reasonable value of his services prior to discharge, the interim fee payments received are deducted from the amount of his claim. If the reasonable value of the architect's services to the time of discharge is less than the amount of interim fee payments he has received, the client is entitled to a refund.

(b) By Client.-Most of the reported appellate cases have involved actions by architects to recover their fees. In some instances, clients have asserted causes of action against the architect on incorrect cost estimates. Sometimes these actions are asserted independently against the architect, ${ }^{11}$ but more often they are the basis for a counterclaim or defense by the client when sued by the architect for fees. In such actions the material issues are: (1) Has the architect promised that the project could be built for a specified amount or merely that he will use due care in making predictions? (2) What effect should be given to contract disclaimers? (3) Has the promise been performed? (4) What is the measure of the client's recovery?

In order not to lose a client, architects may, reluctantly and perhaps unwisely, risk their fee on the accuracy of their cost estimates. ${ }^{72}$ However, they usually do not intend to go farther by promising that the project can be built for a specified amount, nor that they will be accurate.

Normally, both architect and client assume that the architect will use due care in the performance of his work. Whether the architect has used due care depends upon the customary methods of measuring professional competence. He is held to the standard of care of others of his profession with his experience, judged by the standards of the community in which he practices.

Whatever effect disclaimers have upon the architect's right to collect his fee, disclaimers should certainly preclude any action against the architect for inaccuracy. However, disclaimer clauses should have no effect where the architect is negligent.

\footnotetext{
"Pieri v. Rosebrook, 128 Cal. App. 2d 250, 275 P.2d 67 (1954).

"See note 93 and accompanying text.
} 
If the architect has breached, and the project is abandoned, the architect will not be able to collect for his services, since performance of his promise also conditions the client's promise to pay. Also, the client can recover any interim fee payments that have been made, as well as any reasonably foreseeable reliance expenses made valueless or less valuable due to abandonment of the project.

If the client proceeds with the project as designed, complications develop. Presumably, the client has not been damaged, since he has a project which is worth what it cost him. A court might use the diminished economic value of the project as a measure for the client's recovery, if this can be established.

One case did involve a substantial recovery against the architect. In Kellogg v. Pizza Oven, Inc. ${ }^{23}$ the client was a tenant who had made an agreement with his landlord that the landlord would pay up to sixty thousand dollars toward the cost of an improvement being made by the tenant. The improvement cost over ninety-two thousand dollars and the tenant-client had to pay more than thirty thousand dollars himself. The tenant-client recovered from the architect for most of this excess cost.

If the project is completed by the client, a problem arises under the rule of avoidable consequences. Normally, damages which could have been reasonably avoided by the nonbreaching party (here the client) are not recoverable. ${ }^{74}$ Proceeding with the project should not constitute enhancing damages, unless the principal motive was to enlarge the architect's liability. Use of the plans by the client, by itself, should not constitute waiver of any cause of action the client may have for damages.

While use of the plans should not waive the client's right to recover for damages, use does affect the architect's right to be paid for his work. If the use of the plans is accompanied by evidence manifesting a waiver of the cost condition, the architect would be entitled to be paid under the contract. The measure of the architect's recovery in such a case would be the rate of commission times the cost of the project. ${ }^{75}$ If the use is not held to constitute waiver of the condition, the architect's measure of recovery would be based on quasi-contract, or benefit conferred. The architect's breach is likely to cause the court to place a low value on the benefit conferred on the client by the use of the plans.

Any recovery for the use of the plans, whether based on contract or quasi-contract, will be diminished or canceled out by any damages recoverable because of a breach by the architect. This discussion assumes

\footnotetext{
${ }^{73} 157$ Colo. 295, 402 P.2d 633 (1965).

${ }^{74}$ Benenato v. McDougall, 166 Cal. 405, 137 P. 8 (1913).

${ }^{75}$ Harrison v. McLaughlin Bros., 108 Md. 427, 70 A. 424 (1908).
} 
a breach which has not been waived and for which damages are recoverable by the client.

Actions by the client for breach have been rare, and as a rule, unsuccessful. It should be recognized, however, that there is an unmistakable increase in the number of lawsuits against professional persons. Potentially, liability does exist for negligent cost estimates. ${ }^{76}$ This liability is often not covered by professional liability insurance, and probably are not insulated against by contract general disclaimers.

\section{B. Mass Private Lawmaking: A Study of AIA Standard Contracts}

While courts are the visible lawmaking institution, many more transactions are governed by standardized provisions in printed form contracts created by the American Institute of Architects. ${ }^{77}$ Where such forms are used, they usually provide a method for resolving a cost dispute. If one party refuses to comply with the provision, litigation is the usual result. Where there is litigation such a printed form, while not always given literal effect, often controls the judicial determination 6 ff the dispute. The drafters of such mass contracts are probably the most important lawmakers. ${ }^{78}$

${ }^{76}$ Kellogg v. Pizza Oven, Inc., 157 Colo. 295, 402 P.2d 633 (1965); Savage v. Board of School Trustees, 3 D.L.R. 39 (1951) (school district had cause of action for damages for negligent estimate).

"For a discussion of AlA forms see Q. JOHNSTONE \& D. HOPSON, LAWYERS AND THEIR WORK 329-54 (1967).

"This article uses the term "mass lawmaking" rather than "adhesion contracts" for several reasons. First, an adhesion contract usually is drafted by one large contractmaker who is the dominant contracting party. A mass contract of the AlA type is often used by many thousand contractmakers, such as architects. Second, the adhesion contract is usually put on a take-it-orleave-it basis. But if a client wishes to contest the AlA provisions, he often has sufficient bargaining power to do so. He may accept the terms because he thinks they are fair or because he'does not know enough about the transaction.

Admittedly, there are some adhesion overtones. A client might face the same AlA contract if he went to a numher of architects. But usually he could do something about unfair or objectionable provisions. Also, this article could lump architects into a group of contracting parties so tied together by mutual self-interest as to constitute for all practical purposes a single contracting party. But, there are enough differences to label AlA architect contracts as "mass" rather than adhesion contracts. They are used, for various reasons, in thousands of architect-client arrangements.

In the unpuhlished study described in note 1 supra, 113 respondents stated they "usually" used an architectural form such as the AIA contract or the form put out by the California Council of the AlA. Seventy-six said they "often" did so, 76 said they "occasionally" did, and 15 said they "never" used such forms. There are three other survey questions which bear upon this point.

"5. If the client signs a printed form contract in your presence, does he appear to read all the terms and conditions on the printed form?"

$\begin{array}{lr}\text { Always } & 27 \\ \text { Usually } & 88 \\ \text { Sometimes } & 53 \\ \text { Rarely } & 38 \\ \text { Never } & 5 \\ \text { (The rest indicate they do not use printed forms.) } & \frac{511}{211}\end{array}$


A study of the evolution of this form reveals the response of an "interested" private lawmaker to adverse court decisions, and points out some of the difficult legal aspects of cost prediction disputes.

\section{1958}

Document B-101 was issued by the AlA in $1958 .^{79}$ lt was a brief agreement. Paragraph 8 stated:

When requested to do so the Architect will furnish preliminary estimates on the cost of the Project, but he does not guarantee such estimates.

This form ignored most cost prediction problems. It downgraded the architect's cost prediction function by requiring a request from the owner before an estimate had to be given. The 1958 form disclaimed a promise to be accurate but did not treat the more recurring issue of right to be paid. ${ }^{80}$ Perhaps the drafters intended the disclaimer to relieve the architect both from the promise to be accurate and from gambling his fees on the accuracy of his cost predictions. If so, the language was not aptly chosen.

2. 1961

AlA document B-131 issued in 1961 made substantial changes. Section 1-1(c) required the architect to give the owner a statement of

“6. If a printed form agreement is used, do you go over with and explain the general terms and conditions to the clients?"

$\begin{array}{lr}\text { Always } & 72 \\ \text { Usually } & 103 \\ \text { Sometimes } & 67 \\ \text { Never } & 13 \\ & \\ & 255\end{array}$

(Some of the data should be discounted because the answers may be colored by what the architect thinks he "ought to do.")

"7. If a printed form agreement is used, how often are changes made in the general terms on the printed form?"

$\begin{array}{lc}\text { Frequently } & 85 \\ \text { Sometimes } & 110 . \\ \text { Rarely } & 65 \\ \text { Never } & 2 \\ & \\ & 262\end{array}$

It appears that the contracting process is such that the AIA form is the "law" in many transactions. Changes can be made if the client knows what to look for, has a firm idea of what he wants, and is willing to push for them. This transaction does not fit neatly into an "adhesion" slot but, nevertheless, we do have mass lawmaking by the AIA. On the role of attorneys see note 91 infra.

${ }^{79}$ Some of these forms can be found in various editions and printings of the ARCHITECTURAL HANDBOOK, supra note 4 . They are available, at least the niost recent ones, at AlA chapter offices or at the national office at 1735 New York Avenue N.W., Washington D. C. 20026.

${ }^{\circ}$ AIA Doc. B101, § 8 (1958). 
probable construction costs "based on current area, volume or other unit costs." Section 1-2(b) stated that at the end of design development the architect was to submit to the owner

a further statement of the probable construction cost and, if authorized by the Owner, obtain a semi-detailed estimate of such cost.

Section 1-3(b), relating to the architect's performance in drafting construction documents, stated that the architect

shall keep the Owner informed of any adjustments to previous statements of the probable construction cost indicated by changes in scope, requirements or market conditions.

In the 1961 form the term "probable construction costs" replaced "estimates." Also, the owner was now entitled to receive these statements of probable construction costs at the various stages of the architect's performance.

In addition, the 1961 form had some specific language dealing with the problem of excessive costs. Section IV-4 stated:

If a fixed limit of project construction cost is stated herein, or if otherwise authorized by the Owner, estimates of the project construction cost prepared in semi-detailed or detailed form by an experienced estimator will be secured by the Architect during the Design Development or Construction Documents Phase. $^{81}$

Under this paragraph if the owner was interested more in costs than in quantity or quality, he had to authorize the architect to hire an experienced cost estimator, the cost of which would be reimbursed to the architect by the owner under section V-2(b). This paragraph was intended to remove the pressure from the architect of making cost predictions that could be interpreted as binding promises or as conditioning the architect's right to collect his fee.

To further protect the architect, section IV-5 stated:

If the estimated project construction cost or the lowest bona fide proposal is in excess of any limit, stated herein, the Owner shall give written approval of an increase in the limit or he shall cooperate in revising the project scope or quality, or both, to reduce the cost as required..$^{82}$

In both paragraphs, the emphasized language seemed to be an attempt to avoid the admissibility of any oral testimony of a fixed cost limit, something the owner was usually permitted to do under the case law. ${ }^{83}$

"Emphasis added.

"Emphasis added.

"Ritter v. School Dist., 291 Pa. 439, 140 A. 126 (1928); Graham v. Bell-Irving, 46 Wash. 607, 91 P. 8 (1907). 
These provisions could surprise the average owner. He might think that an architect is supposed to be a skillful cost predicter. He might also find that the quantity and quality of the project that he expected and had been led to believe that he could get had to be curtailed because the costs were going to be higher than anticipated. The form represented a contractual recognition of the difficulty of cost prediction and the limited function that is served by the architect in predicting costs. If clients were made aware of this before signing the agreement, there could be no quarrel with such a clause. But burying this important concept in a form contract may not communicate this important limitation to the owner unless it is explicitly clarified in advance..$^{84}$

Also, the clause did not seem to limit the extent to which the owner must lower his sights. The owner should not be required to make substantial changes in quality and quantity or substantial increases in the fixed cost limitation in order to protect the architect. While it is true

${ }^{3}$ See note 78 supra on formation of these contracts. Consider also the results of questions 8, 9 , and 10 which relate to the use of attorneys in their transactions.

"8. Do you advise a private (as opposed to a public) client to seek independent legal advice before signing the contraet?"

\begin{tabular}{lc} 
Always & 43 \\
Usually & 37 \\
Sometimes & 108 \\
Never & 84 \\
& \\
\hline
\end{tabular}

(Allowing for the propensity of the responders to state they do what they think they ought to, the answers show that it will be done rarely.)

"9. To the best of your knowledge, does the private client refer the contract to his attorney?"

$\begin{array}{lc}\text { Always } & 6 \\ \text { Usually } & 69 \\ \text { Sometimes } & 172 \\ \text { Never } & 26\end{array}$

\section{3}

"10. If the client signs the contract in your presence, do you or the client, or both, have an attorney present?"

$\begin{array}{lc}\text { Always } & 0 \\ \text { Usually } & 1 \\ \text { Sometimes } & 10 \\ \text { Rarely } & 106 \\ \text { Never } & 143 \\ & -260\end{array}$

These answers make it relatively clear that attorneys do not play a significant role in the formation process. This makes the AlA's role even more important. It also means that the questioning attitude usually found in attorneys is not likely to be a part of the contractmaking process in these transactions. This means explanations and discussions over terıninology will not be common and are likely to be quite uncommon. 
that the design phase of the architect's work requires a good deal of give and take and cooperation between architect and owner, it would seem unreasonable to force the owner to make a substantial curtailment of quality or quantity when cost predictions go awry. Perhaps section Vl-4 protected the owner from having to make such substantial changes in order to proceed with the project. That clause stated:

If any work designed or specified by the Architect during any phase of service is abandoned or suspended in whole or in part, the Architect is to be paid for the service performed on account of it prior to receipt of written notice from the Owner of such abandonment or suspension, together with reimbursements then due and any terminal expense resulting from abandonment or suspension for more than three months.

If the owner had to make unwanted or substantial changes in the quantity or quality of the project, he could abandon the project. But he would have to pay the architect prior to written notice of abandonment. This might not please an owner who felt he had been led to believe he could get what he wanted at a certain cost or had been led to believe he would not have to pay a fee if the work could not be accomplished within the established cost figure. The owner might argue that if the parties had an agreement under which the owner would not have to pay for design services if the costs exceeded a specific amount, the owner's determination not to proceed was not an abandonment of the contract but merely the occurrence of a condition terminating, at his option, his obligation to proceed. Abandonment could mean a legally unjustifiable refusal to proceed with the project.

Section lV-6 stated:

Since the Architect has no control over the cost of labor and materials, or competitive bidding, he does not guarantee the accuracy of any statements or estimates of probable construction cost.

To buttress other protections we see the traditional "does not guarantee the accuracy" phraseology which was used in the 1958 agreement. This should have negated a promise to be accurate. The paragraph did properly state why such a nonguarantee is fair.

The 1961 form gave considerable protection to the architect. Perhaps such protection would not have included a negligently made cost prediction. The form tended to discourage a cost-conscious owner and relieved the architect from serious responsibility for cost predictions. If read and understood by the owner, the form was fair and should have controlled. Unfortunately, too often the provisions were not brought to the owner's attention or explained by the architect. ${ }^{85}$ 


\section{1963}

AlA document B-131 was revised again in 1963. There were no significant changes in the architect's obligation to furnish statements of probable construction costs at the end of schematic design, design development, and the construction documents phase. But unlike the 1961 form, upon completion of design development. the architect was no longer required to provide a semidetailed estimate of such cost if authorized by the owner.

There were other minor changes. The phrase "project construction costs" was replaced by "probable construction costs." The phrase "estimated project construction costs" was deleted and replaced by "statement of probable project construction costs." There were no essential differences between the 1961 and 1963 forms.

\section{1966}

In 1966 the AlA issued a new form contract. There were no essential changes in the obligation of the architect to give statements of probable construction costs. However, there were major changes in the language dealing with nonnegligent, erroneous estimates of probable construction costs.

In article 3, section 3.4 , the 1966 form states:

Statements of Probable Construction Costs and Detailed Cost Estimates prepared by the Architect represent his best judgment as a design professional familiar with the construction industry. It is recognized, however, that neither the Architect nor the Owner has any control over the cost of labor, materials or equipment, over the contractors' methods of determining bid prices, or over competitive bidding or market conditions. Accordingly, the Architect cannot and does not guarantee that bids will not vary from any Statement of Probable Cost or other cost estimate prepared by him.

Section 3.4 eliminates the professional cost estimator and gives a more detailed and well written recital on why there may be unpleasant surprises when the bids are opened. The clause obligates the architect to make his cost predictions with due care, but does not require that he be accurate.

\section{Section 3.5 states:}

When a fixed limit of Construction Cost is established as a condition of this Agreement, it shall include a bidding contingency of ten per cent unless another amount is agreed upon in writing. When such a fixed limit is established, the Architect shall be permitted to determine what materials, equipment, component systems and types of construction are to be included in the Contract Documents, and to make reasonable adjustments in the scope of the Project to 
bring it within the fixed limit. The Architect may also include in the Construction Documents alternate bids to adjust the Construction Cost to the fixed limit.

In the 1966 form there is a private codification of court-made law and professional custom on a permissible deviation figure. Also, the owner must cooperate in cutting down the quality and must make reasonable adjustments in quantity. Again, such an allocation would be fair if the owner were warned in advance. If such a clause were pointed out in advance, and if the owner had the usual superiority of bargaining power, such a clause might be deleted. If the owner objects to the clause, the architect might assure him that despite the clause control over design details would remain with the owner. But note that this protection only applies where there is a fixed cost limitation. Such provisions are an attempt on the part of the AIA either to discourage the use of fixed cost limitations or to give the architect complete protection in the event a dispute arises over this question.

In addition to requiring the owner to increase a fixed cost limit or to cooperate in reducing quantity and quality, section 3.5.I requires the owner to "authorize rebidding the Project within a reasonable time." It would seem superfluous to both give the architect control over details and require the client to cooperate in revising the scope. Perhaps client control of the scope is so ingrained in custom that section 3.5.1 was needed to legitimate the power of the architect under section 3.5 to control quantity and quality when a fixed limit is chosen. More important, section 3.5.I states that in case the project is revised:

[T] he Architect, without additional charge, shall modify the Drawings and Specifications as necessary to bring the Construction Cost within the fixed limit. The providing of this service shall be the limit of the Architect's responsibility in this regard and having done so, the Architect shall be entitled to his fees in accordance with this Agreement.

Section 3.5.I directly deals with the right to redesign. This is a private law codification of a practice among architects. ${ }^{86}$ It should be noted that redesign is a very expensive operation for the architect. Also, section 3.5.1 for the first time directly confronts the fee problem. Instead of a vague nonguarantee of estimates or a backdoor use of the abandonment clause, there is a direct handling of the fee problem. The architect takes the risk he will have to redesign, but does not risk his fee. This, if made clear to the owner, is a marked improvement.

Note that all of these protective provisions apply only if there is a

\footnotetext{
${ }^{86}$ In the comments made by architects attached to the questionnaires, see note I supra, many stated they would redesign at their own expense.
} 
fixed cost limitation. Earlier forms stated that such a limitation must be "stated herein." This phrase was dropped in 1966. Instead article 12 states:

This Agreement represents the entire and integrated agreement between the Owner and the Architect and supersedes all prior negotiations, representations or agreements, either written or oral. This Agreement may be amended only by written instrument signed by both Owner and Architect.

This integration clause is designed to protect against assertions made by the owner that there had been an agreement for the creation of a fixed cost limitation and a fee contingency, as well as other oral conditions. Whether this clause will accomplish this purpose is questionable. Perhaps the oral condition "exception" will be used, though here performance has commenced. It may take some nimbleness, such as the use of mistake, reformation, fraud or sham to avoid the clause. But if it appears the oral agreement was made, many courts will find a way to consider the evidence of agreement.

The protective provisions apply if there is a fixed cost limitation. If there are cost budgets suggested by the owner, or there are statements of probable costs given by the architect during the course of his performance, these protective provisions will not be needed to give the architect his fee.

\section{Judicial Attitude toward Forms}

The succession of new forms from 1958 to 1966 has shown a recognition on the part of the architectural profession of the gravity of cost prediction problems. They have attempted to provide protection for the architect when cost predictions turn out to be inaccurate. How courts will treat such forms remains to be seen. One recent case may be an indication of how such forms will fare when they are litigated. In Stevens v. Fanning ${ }^{87}$ the architect sued to recover the remainder of the fee claimed under the 1961 AlA contract under which he performed architectural services. The plaintiff asked for $\$ 14,500$ and when he was awarded $\$ 2,500$ he appealed. The owner wanted a new structure designed by the architect which was to house his automobile dealership. Early in the negotiations he informed the architect that the structure was to contain at least forty thousand square feet, not cost in excess of $\$ 250,000$ and be done quickly since his present lease was expiring. The written contract stated that the building was to be a "multiple purpose building suitable to the needs of the Owner, at an approximate estimated cost of $\$ 250,000$." The parties disagreed as to the type of basic construction

3759 Ill. App. 2d 285, 207 N.E.2d 136 (1965). 
materials to be used in the structure. The owner testified that he had been informed that the structure would be made of prestressed concrete and would cost no more than $\$ 250,000$. The architect testified that the prestressed concrete method was an alternate proposal to a steel-framed building. The architect testified that he had advised the owner that prestressed concrete would cost more than $\$ 250,000$, but that additional costs might be justified by insurance premium savings.

Bids were submitted on the basis of both the steel frame and prestressed concrete. The bid for steel construction was $\$ 250,000$, but the bid for prestressed concrete was $\$ 317,000$. At this point the client terminated the architect's performance and refused to pay any fee. The architect tried to use the abandonment clause of the $1961 \mathrm{AlA}$ form, claiming that he was entitled to be paid for his work less an advance payment of one thousand dollars that had been made to him. The owner contended that he had not abandoned the contract, but had terminated the contract because the condition to continue its performance had not occurred. The court held that there was substantial evidence to support the trial court finding that the parties had agreed that the type of construction was to be prestressed concrete and that the cost limit was to be $\$ 250,000$. The architect pointed to a clause under which the owner agreed to cooperate in revising the scope and quality to reduce the cost. In responding to this language the court stated:
Such contention cannot be sustained in that the trial court found that the parties contracted solely for a specific type of building at a given price, and it is undisputed that the architect did not produce such building at the agreed price. $^{88}$

It seems that the court felt that it was finding the true agreement of the parties and that this clause would be disregarded if inconsistent with such finding.

Perhaps other courts or arbitrators would have been and will be more controlled by such clauses. However, the Stevens case indicates a tendency which will periodically appear in the cases. Many courts will try to find the real agreement of the parties and enforce it despite the written contract. Singling out "adhesion" contracts for such treatment is a partial return to the subjective theory of contracts, a theory which never really died. ${ }^{89}$ But such rejection of the form will be less likely to occur where the client was represented by counsel or was quite experienced in construction.

"s $/ d$. at 295,207 N.E.2d at 142.

"The plethora of mistake cases and "meeting of the minds" language show this. See Zell v. American Seating Co., 138 F.2d 641, 646-48 (2d Cir. 1943). 


\section{III}

\section{SOME SUGGESTIONS TO THE LEGAL PROFESSION}

\section{A. Planning}

A recent unpublished study of architectural contracting practices indicates that lawyers do not play a significant role in the formation of contracts between architects and their clients. ${ }^{90}$ If the client is a large organization or a public agency, an attorney for the client may participate in the contractmaking process. However, in many of these transactions neither party will be represented by counsel in the planning stage. This is more likely to be the case when the architect proposes to use a standard form contract. One of the purposes of using such a contract is to avoid the necessity for hiring an attorney.

This means that attorneys who represent architects and those who represent those who engage architects may have to thrust themselves into the contractmaking process in order to avoid the possibility of subsequent disputes over cost predictions. An attorney who represents architects or owners may have to "educate" his clients by suggesting steps be taken to avoid problems.

\section{Bringing Cost Problems into the Open}

The parties must confront the possibility of a substantial variation between anticipated costs and construction bids, with the hope that they can come to a mutually agreeable understanding on how such a problem should be handled. At the very least there should be agreement on the following issues: (l) Will the cost figure used be a cost budget or a fixed cost limitation? (2) If there is a fixed cost limitation, what kind of control will the architect have over quantity and quality and what must the client do if bids are too high? (3) Must the client permit the architect to redesign if there is a fixed cost limitation? (4) Is the architect to be paid for his work if the project is given up because the low bid exceeds a nonnegligent cost prediction?

If these basic questions can be answered to the mutual satisfaction of the parties, the common understanding should be clearly and completely expressed in a written contract. The written contract need not be a long and detailed form contract. It can be encompassed within the parameters of an informal letter agreement which covers the basic architectural services, extra services, client obligations, computations, payment of the basic fee, and what expenses are reimbursable. 


\section{Explanation of Form Contracts}

If a form contract is used, it is important for the crucial provisions to be pointed out and explained to the client. If there is a full discussion in advance of executing the contract, the necessity for pointing out the crucial language and explaining it becomes less important.

\section{Breaking a Negotiation Impasse}

Attorneys must also recognize that there is the possibility that architect and client will not be able to come to a mutually agreeable solution. The client may insist that he should not have to pay for architectural design services if the project is abandoned because of excessive costs. The architect may insist that he cannot take the risk that he will go unpaid for his design services. It is important for attorneys to be able and willing to suggest solutions which may be acceptable to both parties when such an impasse arises.

If the impasse develops because the client insists and has sufficient bargaining power to demand that the architect assume the risk that the project cannot be completed within the fixed cost limitations, there are methods of making this more palatable to the architect. The architect might suggest that he be paid a slightly higher fee if he has to assume this risk.

Related to a higher fee is the possibility that the fee be based upon a measurement other than percentage of construction cost. This method of computing the fee has exacerbated an already difficult problem. Since the fee increases as costs go up, some clients think the architect is not truly interested in keeping costs down. Also, smaller jobs, according to the architects, do not involve a high enough fee to justify the careful, detailed cost breakdowns which can produce an accurate cost prediction in many situations. This is recognized in the suggested fee for residences being higher than other projects. ${ }^{91}$ But even this differential may not be enough.

Thought should be given to a fee based upon a specified multiple of personnel hourly rates or upon cost plus a fixed fee. ${ }^{92}$ The latter method of compensation can avoid the frequent disputes over reimbursables. Allowable costs should be defined in the contract. If the client is concerned about an open-ended fee, there can be a fixed fee limit agreed in advance. If the architect has limited bargaining power and is operating in a very competitive market, a cost type contract may not be

"See ARCHITECTURAL HaNDBooK, supra note 4, § I 4.03.

${ }^{92}$ See AIA Doc. B23I, $\S \S 1,11$ (1966) which uses a personnel multiplier method of compensation and STANDARD FoRM 1966 , supra note $8, \S \S 1,11$, which uses fee plus professional expenses as a method of compensation. 
feasible. The architect may request that he be given a larger permissible deviation from the fixed cost limitation figure than the customary ten percent. The architect could ask for some control over who and how many bidders are invited to bid as well as the right to ask for new bids. $\mathrm{He}$ might insist that he should have the right to redesign at his own expense if the low bid is greater than the tolerance specified. He might request the right to control certain details relating to quantity and quality, within some limits, if he is forced to take the risk that he will go unpaid in the event the project is abandoned because of excessive cost.

Perhaps in some situations the architect may be in a good bargaining position and insist that he will not assume the risk that he will go uncompensated if his cost prediction, through no fault of his own, turns out to be inaccurate. Under such circumstances, the client might request that the fee be based upon the final statement of probable construction costs rather than upon the low bid submitted by the contractor. The client might suggest a fee schedule under which the percentage of construction costs will decrease as the costs go beyond certain stated amounts.

If there is extreme disparity of bargaining power, one party may not be able to soften the risk which he is forced to take. However, many times the dominant bargaining party will be willing to make concessions if he does not think these concessions will cost him too much, if he thinks the concessions are reasonably fair, and if both architect and client can be persuaded that a successful design solution will require that the parties believe the deal is fair to both. Halfhearted performance can result from a feeling of forced capitulation on major issues.

\section{Some Suggestions to Architects' Attorneys}

There are certain things which the attorney for the architect must consider in the planning stage. At the outset he must impress upon the architect that cost prediction is a part of architectural service that is important to the client and can result in a lost fee if things go wrong. The architect's attorney must try to get the architect to discuss these matters fully and frankly with the architect's client in advance if the architect does not wish to run the risk that he will not be paid for his services. The architect must be persuaded that he cannot rely upon a form contract to give him protection and avoid the necessity of discussing potential problems. The architect must be persuaded that if the quantity and quality desired by the architect's client cannot possibly be achieved within the amount of money the client wishes to spend, that he must insist at the outset that the client either reduce quantity or quality or raise his cost budget. This may mean that the architect's client will take 
his business to another architect. If so, this may in the long run be advantageous to the architect. If the client expects to get too much for the amount he expects to pay, trouble is bound to occur.

An architect who is hesitant to go into these matters in detail with a client to avoid the unpleasantness of what appears to be unprofessional bargaining might be persuaded to turn this over to his attorney if he has confidence that the attorney will be tactful and patient. Also, if the architect does not wish to appear to be backing out of an earlier agreement or causing difficulties in the negotiation by either refusing to assume the fee risk or refusing to assume the risk without protection, he may find it advantageous to inform his client that these are matters upon which his attorney has advised him he cannot compromise. In this sense, the attorney can often serve as an excuse for the architect who does not wish to appear to be a hard bargainer or too insistent upon contract terms.

Another important step in the planning stage is to insure that the contract between the architect and his client contain a provision for interim fee payments, coupled with a strong direction to the architect that such fees be collected as they are due. The presence of such a clause and collection of interim fee payments may be persuasive to the courts in indicating that any cost figures discussed were a cost budget and not a fixed cost limitation. Also the architect is in a much better position if he has been paid and the burden is upon the client to commence litigation. An architect might be ahead in the longrun if he does not raise these problems and occasionally loses a fee when anticipated costs are substantially exceeded by the low bid. The architect may take a calculated risk of avoiding discussion for fear that bringing the matter into the open will cost him his client. This is a determination for the architect to make. However, his attorney should point out the risks to him and methods of minimizing them before the architect makes his choice.

Attorneys for clients who engage architects can help in avoiding conflicts. They can communicate to their clients the reasons for the architect's unwillingness to gamble his fee upon the accuracy of his cost prediction. ${ }^{93}$ They should also make it clear that if the reason for the

\footnotetext{
"Some architects have indicated that such a "gamble" is unethical if not downright immoral. Mandatory Standard II-2 of the AIA Standards of Professional Practice provides that, "An Architect shall not render professional services without compensation." ARCHITECTURAL HANDBOoK, supra note 4, at A-2.04. But it goes ôn to explain that he should not do work without pay conditional on his getting the job. This is different than a fixed cost limitation, which is part of a contract. Howevcr, such speculative, contingent arrangements are made. Questions 10, 1I, and 12 of the unpublished architectural study described in note 1 supra stated:
} 
variance between cost prediction and low bid is due to the negligence of the architect, the client will not have to pay for architectural services. Finally, it may be useful if the attorney for the person engaging the architect indicates to his client that if he wishes to use the design and administrative skills of this particular architect, the client should do nothing unreasonable to jeopardize the close relationship necessary between the architect and his client. If the client is intransigent, and the architect realizes this, the client may lose a good architect or he may employ an architect who does not put forth the maximum amount of effort on behalf of his client. If, after all the facts are before the client, he still wishes to create a fixed cost limitation, his attorney should make the best arrangement he can on behalf of his client. The attorney should keep in mind that the best interests of his client may be served by a mutually satisfactory and fair arrangement.

\section{Participants in Drafting of Mass Contracts}

In discussing planning to avoid problens, some mention should be made of those attorneys who participate in the promulgation of standard forms such as those used by the AIA. These attorneys should realize that they are defining the rights and duties of many persons, and that they are creating mass private law within the limits of autonomy allowed by courts in litigated cases. These lawyers are, for all practical purposes, legislators and should consider their position as one of trust and responsibility. Their function should not be solely that of maximizing protection for architects. Forms which have the seal of approval of a professional association, such as the AlA, may appear to the architect's

“10. Have you ever made a contingent agreement with a client by which your getting your fee depended upon the cost being within a cost ceiling or limitation?"

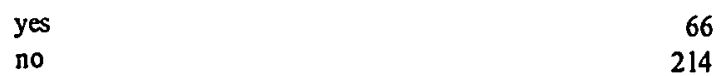

"11. If you answered "yes" in 10, how frequently have you done so?"

$\begin{array}{lc}\text { Usually } & 8 \\ \text { Often } & 13 \\ \text { Seldom } & 42 \\ & \frac{63}{}\end{array}$

"12. To the best of your knowledge such speculative arrangements in the practice of architecture are:"

$\begin{array}{lr}\text { Common } & 33 \\ \text { Occasional } & 101 \\ \text { Quite uncommon } & 100 \\ \text { Unheard of } & 32\end{array}$

The answers to question 12 are remarkable. That 32 should find them "unheard of" while 33 find them "common" shows either a refusal to confront reality or a wide variation in practice. Unethical or not, it is done. 
client to be a form which is intended to be fair to both parties. The AlA has too often incorporated language intended to protect the architect, without a proper consideration of the reasonable expectations of the client and normal architectural practices. If the drafters of such standard forms incorporate provisions which change the roles traditionally played by architects in design and in construction, they may be planting the seeds for misunderstanding and litigation. Whenever the reasonable expectations of the client collide with the standard form, there is a strong likelihood that the professional relationship will break down and litigation will result. Further, there is the possibility that courts will refuse to enforce the form language literally, preferring instead to search for the "real agreement" of the parties.

\section{B. During Performance}

The architect's attorney should inform the architect of the steps to take during the course of his performance in order to avoid or reduce difficulties over cost predictions. The architect should keep the client informed on anticipated costs. Where feasible, the architect should educate his client on how cost predictions are made and the not uncommon variation between even reasonably prepared cost predictions and bids by contractors. When work submitted for client approval involves changes from earlier statements of probable construction costs the architect's letter of transmittal accompanying the work to be approved by the client should indicate why these changes in costs have resulted. Also, the client's acceptance of any stage of the architect's performance should be phrased in such a way as to indicate approval of any increase in projected costs. If a suggested design change by the client will affect the projected cost, the architect should inform the client of the approximate additional cost of the suggested design change. If the architect is proposing a change, he should notify his client of the probable effect of this change on earlier cost predictions. Additional costs due to changes may be covered when the architect's work is submitted to the client for his approval. However, even during the performance of these various stages, the architect should communicate any changes in quantity or quality which he is suggesting and the effect of those changes on any earlier cost predictions. The client must be kept aware of costs and indicate his approval of any changes which affect costs.

Attorneys for architects should advise their clients to keep careful records of any conversations or communications between themselves and their clients. If decisions are made over the telephone, it is essential to keep a memorandum of such conversations and preferably send a copy 
to the client as soon as possible. Approvals and orders to proceed with subsequent stages should be formalized in writing and kept for a reasonable period of time.

\section{After Disputes Arise}

When cost disputes do arise, it is extremely important for the attorneys to dig carefully into the facts and try to find out the nature of the understanding between the architect and his client. In doing so, they should avoid placing an undue reliance upon language expressed in form contracts which may have adhesion overtones. Unless it is reasonably clear that the client understands the terminology employed and had his attention directed to the particular language, judicial decisions may result which will not give the language literal effect. When form contracts are used in such a setting, there is always the possibility that the court will try to determine the understanding of the parties in entering into the agreement, especially from the standpoint of the client, and minimize or give no effect to provisions in the form contract.

Litigation results in such cases are uncertain. Sometimes evidence of an antecedent oral agreement will be received despite a subsequent writing and sometimes it will not. ${ }^{94}$ Sometimes disclaimers will be effective, and sometimes they will not..$^{95}$ Prediction in waiver situations is always difficult. For this reason, it is important for attorneys to be able to suggest compromises which can avoid litigation. Fee reduction and stretched-out payments are obvious possibilities. By the time the attorneys enter the picture, redesign and other planning solutions may not be feasible.

Often form contracts contain provisions for arbitration of disputes. ${ }^{96}$ If not, it is possible to submit such disputes to arbitration. If the arbitrator is someone knowledgeable in the construction industry, he may be more sympathetic to the position of the architect than would be a judge or jury. He may be aware of the difficulties in predicting costs.

If litigation does arise, a careful development of the facts of the particular case and of the difficulty of prediction costs in general are far more important than lengthy bickering over admissibility of evidence and stubborn insistence that the language of a form contract should control the result.

${ }^{94}$ Compare Minick v. Kades, 60 Dauph. 66 (Pa. 1949) (not admitted), with Rosenthal v. Gauthier, 224 La. 341, 69 So. 2d 367 (1953) and Spurgeon v. Bueliter, 192 Cal. App. 2d 198, 13 Cal. Rptr. 354 (1961). For a Pennsylvania case which admitted the parol evidence see Levy v. Leaseway System, Inc., 154 A.2d 314 (Pa. Super. Ct. 1959).

${ }^{95}$ Compare Mitterhausen v. South Wis. Conference Ass'n, 245 Wis. 353, 14 N.W.2d 19 (1944) (disclaimer effective) with Spitz v. Brickhouse, 3 Ill. App. 2d 536, 123 N.E.2d 117 (1954).

${ }^{9}$ See STANDARD Form 1966, supra note 8, art. 11. 


\section{Deciding Disputes}

Despite all possible preventive measures, some cost disputes will arise and find their way to arbitration or litigation. Some cases are relatively easy to decide. If the cost prediction has not been made with due care, the architect should not be able to collect for his services. In addition, he should be liable for any foreseeable damages caused by his negligence which could not have been reasonably avoided by the client. If the architect has received interim fee payments, the client should be able to recover them, less any benefits which may have been conferred on the client by virtue of the architect's work.

Other easy cases are those where the reason for the cost prediction exceeding the low bid are unjustifiable acts by the clients or manifestations by the client of a willingness to pay without regard for any fixed cost limitation being met. ${ }^{97}$ ln such cases the condition is excused and the architect should be paid for his services even if the project is abandoned.

Estoppel, one of the principal doctrines used to excuse the condition, usually requires a reasonably foreseeable change of position in reliance upon acts or inaction by the other party. In the cost condition cases, the client cannot assert a cost condition if he led the architect to believe reasonably that the condition would not be relied upon. Analytically, the architect would have to be able to show that he could have complied with the condition had he not been misled. For example, where changes result in additional costs, to excuse the cost condition on the basis of estoppel it would be necessary to show that the ordering of changes by the client led the architect to reasonably believe that the cost condition would be disregarded by the client. To do this the architect would have to show that the client knew or should have known that the requested changes would have a substantial effect upon the cost, and that the client should have realized that the architect would rely detrimentally by not designing in a way as to meet the cost condition. Also, the architect would have to show that he would have been able to meet the

\footnotetext{
${ }^{97}$ There is a good deal of overlap in these concepts. For example, ordering excessive changes could: (1) Prevent the architect from complying with the condition; (2) hinder him from doing so; (3) lead the arehitect to rely by making it appear the client no longer cares about the cost condition; (4) manifest an intention to pay the fec despite the failure of the condition to occur; (5) make performance of the condition impossible.

Also, interpretation could be used. The cost condition could be to design a given project which will eost a designated amount of money unless excessive design changes are made by the client. The same analysis could be made of using plans, refusing to permit a representative number of bidders or any other acts of a similar nature. If interpretation is used rather than excusing the condition, this could affect burden of proof.
} 
cost condition. Even in cases where estoppel is the announced doctrine, such requirements may be glossed over if estoppel is thought of as a simple "fairness" doctrine.

An even simpler way of avoiding these requirements is to use waiver. Even here some authorities require that the condition not be a material part of the agreed exchange. ${ }^{98}$ This is a difficult concept to apply in a cost condition case.

In some cases courts have ignored these analytical distinctions and used waiver without an inquiry into the nature of the condition. ${ }^{99}$ This despite the analytical imprecision makes sense. A condition is excused to avoid undue forfeiture or unjust enrichment or if there is credible evidence that the party entitled to the condition intended to give it up. If the act upon which the waiver is predicated is unequivocal in showing this intention, this is enough. But care should be exercised when such intention is predicated upon ambiguous acts, such as the use of plans, payment of interim fees, or inclusion of a provision for interim fee payments in a contract. But even in these cases it may be desirable to avoid forfeiture or unjust enrichment. If possible, quasi-contract should be used. ${ }^{100}$ If quasi-contract cannot be used, then waiver is useful and desirable even if the evidence of an intention to dispense with the condition is somewhat unclear.

Other cases which are relatively easy to resolve are those where the parties make a conscious risk allocation one way or the other. On the one hand, the architect will not be paid unless he is accurate, where he has expressly assumed this risk. On the othor hand, if a cost budget has been agreed upon, the client must pay because he has assumed the risk by contract. However, the fact that the parties have assented to a form contract should not invariably mean that they have allocated the risk by contract. If the assent is to a standardized form contract and it is relatively clear that the client did not have crucial provisions pointed out to him and explained, the contract should not allocate the risk. Conversely, the undisclosed intention or "understanding" of the client that he would not have to pay should not be cleterminative.

The most difficult case is one where the architect has not been negligent in making his cost prediction, where the owner has done

98 See, e.g., RESTATEMENT OF CONTRACTS $\S \S 288,297$ (1932).

${ }^{99}$ See, e.g., Arata v. Sunseri, 147 So. 2d 222 (La. Ct. App. 1962); Mercier v. Munich, 9 La. App. 372, 120 So. 522 (1928); Bissell v. McCormack, 162 Wash. 482, 298 P. 697 (1931).

${ }^{100}$ Quasi-contract will be difficult where the client has not used the plans and it therefore appears that there is no benefit to the client. See Rowell v. Crow, 93 Cal. App. 2d 500, 209 P.2d 149 (1949). Also, sometimes courts will not apply quasi-contract where there is an express or implied-infact contract. See, e.g., Goodman v. Motor Products Corp., 22 Ill. App. 2d 378, 161 N.E.2d 31 (1959); Smith v. Stowell, 256 lowa 165, 125 N.W.2d 795 (1964). 
nothing to waive any fixed cost limitation which may have been created, and where the risk was not clearly allocated in the contract. We cannot be certain of contractual assumption of risk if: (1) Any cost figure is not clearly designated and agreed to as a budget or a fixed cost limitation; or (2) There is a clear agreement that any figure is a fixed cost limitation, but it is not clear that the architect is to go unpaid if the project is given up because bids substantially exceed projected costs. Where there is no negligence, no excuse of condition, and no contractual assumption of risk, should the architect be paid for design services performed even though his work has not been of value to the client? ?101 $^{10}$

There is one reason which could tip the balance in such a case against the architect. Similar to the doctrine under which contracts are interpreted against the party preparing them, it might be possible to allocate this risk to the architect based upon his greater knowledge of the problem and the fact that he could have clarified the difficulty in advance. Perhaps this explains judicial hostility to architect compensation claims where bids exceed anticipated costs. ${ }^{102}$

But the allocation of loss in such a case could be based to some degree on ability to pay. In many instances, these losses can have a devastating effect on the architect. A few losses of even small fees can mean the end of an architectural practice. An architect must have a lengthy education and an apprenticeship at low pay, often for a long period, before he is permitted to take a difficult licensing examination. Generally, he is not well paid ${ }^{103}$ and his practice is faced with difficult and often impossible fee collection problems. To require that architects bear the risks where they are not negligent is too great a sanction. The refusal of the client to proceed with a project under such circumstances may injure the reputation of the architect and this is a severe sanction. Architects are not entrepeneurs, and they do not have the opportunity of large entrepreneurial gains. All they can sell are their services. They

${ }^{101}$ In this regard we must watch for a client who wishes to avoid a fee, ostensibly "abandoning" the project and then, without paying the fee to the architeet, using his design ideas. In such cases, this "brainpicking" should entitle the architect to damages or restitution based upon a breach of the implied obligation of fair dealing. If the use of the design ideas was not part of a scheme to cheat the architect, quasi-contract should be sufficient.

${ }^{102} C f$. Andry v. Ewing, 15 La. App. 272, 130 So. 570 (1930).

${ }^{103}$ It is difficult if not impossible to collect hard data on income of architects. Information is difficult to gather, hard to cvaluate, and quickly goes out of date. The conclusion in the text is based upon information on starting salaries of architects compared to lawyers gathered by the authors from law schools and the Department of Architecture of the University of California at Berkeley, discussions with architects, and comments made by architeets written on the questionnaire discussed in note I supra. For a 1949 study see American INSTITUTE of ARCHITECTS, The ARCHITECT AT Mid-Century: Evolution and ACHIEvement, app., table 10 (1954). 
should not be deprived of their fees when they have performed their services with due care. It should be noted that insurance does not protect them from these risks..$^{104}$

\section{$\mathrm{V}$}

\section{CONCLUSION}

Much of the responsibility for cost prediction problems rests with the architectural profession. Too many architects do not seem to be able to do a reasonably accurate job of estimating costs. This may be due to inexperience, lack of past cost data, time pressures, the fee structure, the unstable construction industry, a fluctuating money market, inflationary building costs, and the constant development of new materials and construction techniques.

Improvements in cost estimating accuracy can result from collection, storage, and the retrieval of prior cost data through the use of computers. Professional associations should be instrumental in the development of this data and its dissemination on a reasonable cost basis to individual architects. ${ }^{105}$ Increased development of cost prediction skills by architects within large architectural organizations should also improve the accuracy of cost predictions.

Another reason for these disputes is the reluctance of many architects, especially younger ones, to confront a client with the incompatibility of his design desires and what he wants to spend. Fear of losing a client often causes such architects to gloss over such incompatibility.

Some architects do not inform their clients that cost predictions are difficult nor do they clarify who bears the risk of an inaccurate cost prediction. Such advance discussions can, if properly structured, result in a common understanding on the architect's function and his responsibility for cost predictions. Too often architects rely upon language of a printed form contract which is not likely to be read or understood by the client.

Though major responsibility lies within the architectural profession, attorneys can by proper counseling reduce the likelihood of disputes and misunderstandings. When such disputes do arise, emphasis must be placed upon the professional nature of the architect-client relationship.

\footnotetext{
${ }^{10 x}$ Obviously, uncompensated services are not covered by professional liability insurance. As for liability, there is usually an exclusion for express warranties, estimates of probable construction costs and cost estimates being exceeded. See Continental Casualty Company, Architects' and/or Engineers' Professional Liability Policy RDAE 970, Part 11, 1 (k).

${ }^{10 s}$ See Szuprowicz, Computer Cost Analysis, in Creative Control of BuILding Costs, supra note 6 , at 139 .
} 
Unfortunately, many courts apply standards more appropriate to arms length transactions and the sale of off-the-shelf goods. The architectclient relationship involves a coordinated effort to solve the design problem in the best possible manner. The architect's function in predicting costs is to supply an intelligent professional opinion on anticipated construction costs. If he does so, he should not take the risk that he will go unpaid for his services. Only if the evidence clearly manifests that he has assumed this risk should a cost condition be found and the architect denied his fee. 